\title{
The role of leptin in patients recovering from Anorexia Nervosa
}

\author{
Zuzanna Rząd ${ }^{1} \mathrm{ADF}$, \\ Joanna Rog ${ }^{2}$ E, https://orcid.org/0000-0003-4057-9507 \\ ${ }^{1}$ Independent Public Clinical Hospital No 1 in Lublin, Poland \\ ${ }^{2}$ I Department of Psychiatry, Psychotherapy and Early Intervention, Medical University of Lublin, Poland
}

\begin{abstract}
Introduction: Anorexia nervosa (AN) is a mental disorder with the highest death rate. The characteristic feature of AN is endocrine dysregulations, including changes in adipose-tissue secreted hormones, especially adipokines. The most widely studied of them is leptin whose role in the pathophysiology and prognosis of AN is confirmed in more and more studies. The aim of the study was to summarize the role of endocrine disruptions with particular emphasis on leptin in the pathophysiology of AN.

Material and methods: For the literature review, the electronic databases PubMed, Cochrane and Google Scholar search were used with the following keywords: eating disorders, adipokines, leptin, metreleptin, satiety, hunger, anorexia, obesity, for studies listed from database inception to October 2021.

Results: Leptin, produced mainly by white adipose tissue, inhibits the hunger center in the hypothalamus by negative feedback with ghrelin secreted by the gastrointestinal tract. Leptin is involved in numerous biological functions, including body weight regulation, innate and adaptive immunity regulation, reproduction, and bone formation. Studies confirm decreased leptin levels in AN individuals. In recent years, extensive experience has been gained with leptin as a drug in clinical trials. The studies suggested that treatment can restore menstrual function and bone health and improve mood with unclear body weight effects. Conclusions: Focusing on leptin-related changes is a promising approach to improve AN management. Assessment of leptin levels in AN patients could be a useful tool for therapy monitoring. Treatment with leptin could reverse unfavourable changes induced by diet restriction, including mood symptoms, loss of bone mass and menstrual function. However, the results of these studies need confirmation on larger groups of patients.
\end{abstract}

Keywords: anorexia nervosa, eating disorders, leptin, adipokines

\section{Streszczenie}

Wstęp: Anorexia nervosa (AN) jest zaburzeniem psychicznym o dużej śmiertelności. U pacjentów obserwuje zaburzenia endokrynne, w tym zmiany w sekrecji hormonów tkanki tłuszczowej, szczególnie adipokin. Jedną z najbardziej przebadanych adipokin jest leptyna, na której rolę w patofizjologii i rokowaniu AN wskazuje coraz większa liczba badań. Celem pracy było podsumowanie wiedzy dotyczącej zaburzeń endokrynnych, ze szczególnym podkreśleniem leptyny, w patofizjologii AN.

Materiały i metody: Do przeglądu literatury wykorzystano elektroniczne bazy danych: PubMed, Cochrane i Google Scholar używając następujących słów-kluczy: eating disorders, adipokines, leptin, metreleptin, satiety, hunger, anorexia, obesity dla prac opublikowanych od założenia bazy do października 2021.

Wyniki: Leptyna, produkowana głównie przez białą tkankę tłuszczową, hamuje działanie podwzgórzowego ośrodka głodu przez ujemne sprzężenie zwrotne wydzielania greliny w przewodzie pokarmowym. Leptyna jest zaangażowana w liczne funkcje biologiczne organizmu, w tym regulację masy ciała, odporności wrodzonej i nabytej, funkcje reprodukcyjne oraz procesy kościotworzenia. Badania potwierdzają niższe stężenia leptyny u osób z AN. W ostatnich latach prowadzonych jest coraz więcej badań dotyczących leczenia leptyną. Badania sugerują, że farmakoterapia może odwrócić niekorzystne zmiany hormonalne i kostne oraz wpływać pozy tywnie na nastrój. Niejasny pozostaje wpływ leczenia leptyną na masę ciała.

Wnioski: Ocena poziomu leptyny u pacjentów z AN może być uży tecznym narzędziem monitorowania terapii. Leczenie leptyną może odwrócić niekorzystne zmiany wywołane restrykcjami diety, w tym objawów zaburzeń nastroju, utraty masy kostnej i czynności menstruacyjne. Wyniki badań wymagają jednak potwierdzenia na większych grupach pacjentów.

Słowa kluczowe: anorexia nervosa, zaburzenia odżywiania się, leptyna, adipokiny 


\section{Introduction}

For five years, the World Day for Combating Eating Disorders has been celebrated on June 2, and the Day for Combating Anorexia on May 6. The intention of such campaigns is to raise global awareness of eating disorders (ED) as diseases that can be fatal if left untreated. Anorexia nervosa (AN) is a mental disorder with the highest death rate [1]. In general, at least one person in the world dies every 62 minutes due to an ED. Therefore, both psychotherapeutic and pharmacological treatments of AN still need improvement [2]. Contemporary discourse on AN addresses the question of whether absolute body control is an expression of exemplary self-control (and body) or a mark of inexpressible suffering. A broad view of the problem of ED allows for a better explanation of the mechanism of action, more effective coping with the disease and its consequences.

AN most often affects young women, what is confirmed by population studies conducted in the USA, which found that at any point in life, up to $0.1 \%$ of young men and $0.3-0.4 \%$ of young women will suffer from AN [3]. In women, a characteristic feature of AN is global endocrine dysregulation, including dysfunction of the hypothalamic-pituitary-adrenal (HPA) axis, disturbance of the level of adipokines regulating appetite and hormones [4]. When weight loss occurs, patients are rewarded internally by a positive sense of control over their eating habits and body weight. At an equivalent time, the physiological response to a reduced energy intake sets in, which in its continuation entails the wellknown symptoms of starvation encountered in acutely ill individuals. The primary behaviours lead to initial and prolonged weight loss and, with time, to adaptation to starvation. Entire spectrum of the disease characteristic clinical phenotype, which incorporates somatic, cognitive and behavioral symptoms, was observed. At this stage, the initial desire to reduce body mass was replaced by an urge to still do so. Loss of control over energy intake and body weight was appearing [5].

Approximately $50 \%$ of women with $\mathrm{AN}$ recover, about $30 \%$ only partially recover, while the rest have recurrent remissions of the disease. Although endocrine disruptions are mainly caused by adaptation to a low energy state, they may have long-term detrimental effects on skeletal health and concomitant neuropsychiatric diseases. Understanding the mechanisms behind the endocrine complications of AN is important given the chronic nature of the disease and the current severity of symptoms associated with the COVID-19 pandemic [6]. The endocrine disruptions include changes in adipose-tissue secreted hormones, especially adipokines. The most widely studied of them is leptin, a pleiotropic hormone that regulates many physiological processes. More and more studies confirm the role of leptin in the pathophysiology and prognosis of AN.

This study aims to summarize the role of endocrine disruptions, with particular emphasis on leptin, in the pathophysiology of AN and the role of its levels on mental and physical states of malnourished patients. In addition, we also discussed therapy trials where administration of an analogue of human leptin was used. For searching, the electronic databases: PubMed, Cochrane and Google Scholar were used. The content that was looked for was dated from database inception to October 2021, with the following keywords: eating disorders, adipokines, leptin, metreleptin, satiety, hunger, anorexia, obesity.

\section{Endocrine activity of adipocytes}

Adipocytes are the main building blocks of adipose tissue, which is one of the active organs of internal secretion. Adipocytes produce biologically active protein compounds called adipokines, which exert local (autocrine and paracrine) and endocrine effects on distant organs. So far, several hundred adipokines have been identified, differing both in terms of structure and function. They regulate: cellular metabolism, angiogenesis, blood pressure, immunity and inflammation; maintain energy balance, are responsible for the feeling of hunger and fertility-related processes [7]. Most often described adipokines include leptin, resistin, apelin, visfatin, vaspin, adiponectin [8]. Due to its multidirectional action, adipose tissue plays a key role in the regulation of metabolism in the body, and its endocrine effect is clearly visible in extremely different states, such as obesity or AN [9]. In 2019 the results of a meta-analysis showed lower levels of leptin and resistin in AN compared to healthy individuals. In comparison to the control groups, patients had higher blood levels of adiponectin, vaspin and the soluble leptin receptor [10].

\section{Leptin}

Leptin, discovered in the 1990s, is a 167 -amino acid product of the Lep gene, which structurally belongs to the cytokine family. It is the best described and known adipokine, produced mainly by white adipose tissue (WAT), and to a much lesser extent by the placenta, ovaries, testes, stomach, liver, pituitary, vascular endothelium, brown adipose tissue, skeletal muscles and cells epithelial lesions of the mammary gland in women [11]. Leptin inhibits the hunger center in the hypothalamus by negative feedback with ghrelin secreted by the gastrointestinal tract. Its synthesis is influenced by the size of adipocytes: the larger cells release, the greater amount of hormone. The decreased mass of adipose tissue in the body is reflected by hypoleptinemia. This state is a characteristic parameter of patients suffering from AN. In 
some studies, AN individuals tended to have leptin levels below the fifth percentile of the age-matched reference range [12]. In the meta-analysis, lean women have higher leptin levels than these suffering from AN [10].

The mutation of the Lep gene is associated with morbid obesity and severe appetite [13]. In individuals with excessive body mass, the reduced sensitivity to leptin occurred, leading to impaired satiety despite the supply of large amounts of energy and high levels of the hormone [14]. The increased levels correlate with body mass index and insulin resistance in patients with type 2 diabetes and enhance the synthesis of pro-inflammatory factors. Leptin is involved in numerous biological functions apart from weight regulation: innate and adaptive immunity regulation, reproduction, and bone formation [15].

\section{Hypoleptinemia as the Endocrine Trigger}

A prolonged negative energy balance (reduced energy intake relative to energy expenditure) leads to starvation and triggers complex neuronal, metabolic, hormonal and behavioral adaptations to promote survival. The maintenance of energy supply for the brain, and therefore the protecting lean mass, are crucial within this process. A decrease in insulin and an increase in counter-regulatory hormones levels changes main source of energy from carbohydrate to fat. Further processes include decreased thyroid and gonadal hormones levels, increased adrenal glucocorticoids production, decreased body heat, and increased appetite, all of which encourage gluconeogenesis to deliver glucose for critical cellular function and fatty acids for skeletal muscle utilization. Importantly, fasting state reduces energy usage by suppressing thyroid thermogenesis and limiting reproduction and growth [2].

Leptin is a critical endocrine trigger for the adaptive mechanisms that increase the chances of survival during starvation. The adipokine is a pleiotropic hormone and has several courses of action involved in the regulation of energy homeostasis, and several findings suggest that it may be involved in the regulation of bone mass via changes in the neuroendocrine profile or a central relay. As fat mass decreases during a negative energy balance, circulating leptin levels fall below crucial thresholds, triggering cascades that alter the adaptation to starving step by step. In parallel to the reduced secretion of hormone upon food restriction, both the hypothalamic [16] and peripheral leptin receptors are upregulated [17], indicating an elevated sensitivity to them during starvation. Amenorrhea, hematological changes, depressed mood, resistance, and repetitive food thoughts seem to be clinically relevant examples of starvationrelated symptoms that may have been triggered or impacted by hypoleptinemia [18].

Leptin is thought to be a regulator of kisspeptin neurons in the hypothalamus, which sends signals to neurons expressing gonadotropin-releasing hormone. Significant reduction in gonadotropin-releasing hormone secretion caused by prolonged fasting, will stop the normal production of follicle stimulating hormone and luteinizing hormone. Such changes in endocrine system lead to hypothalamic amenorrhea. In females with AN, the energy deficit caused by nutritional deprivation typically results in hypothalamic amenorrhea, which contributes to impaired skeletal integrity [4]. Females with AN, who have hypothalamic amenorrhea, have low levels of estradiol and androgen. Estradiol works by inhibiting bone resorption by inhibiting RANKL secretion, which enhances osteoclastogenesis and osteoclastic activity, and increasing osteoprotegerin secretion, which inhibits osteoclastogenesis and osteoclastic activity. Estrogen promotes bone formation by inhibiting the secretion of sclerostin, a factor which inhibits osteoblast differentiation. Research shows that having amenorrhea for a prolonged period of time is correlated with low skeletal integrity [19].

It has been hypothesized that the hypoleptinemia in AN may also contribute to the more frequent comorbid mood disorders. Clinicians noticed that the mood of a patient improves during weight restoration - potentially as a consequence of an increased leptin synthesis. This result was supported by studies on animal model. Leptin-deficient rodents exhibit more severe depressive behaviour than normal mice in forced swim experiment, and normalized levels of hormone administration significantly improve such a symptoms of drop mood [20].

\section{Potential Benefits of Treatment With Recombinant Human Leptin}

In recent years, extensive experience has been gained with recombinant methionyl human leptin as a drug in clinical trials in obese or lipodystrophic patients. Research has shown that people with adipokines deficiency lose weight dramatically after leptin treatment. Most pharmacological trials uses metreleptin in the treatment of obesity. Replacement therapy with leptin has been shown to significantly improve the metabolic profile of lipodystrophic patients in a long-term clinical trial $[22,23]$.

The Food and Drug Administration (FDA) and the European Medicines Agency (EMA) [24] authorization of metreleptin for the management of lipodystrophy allows for conducting clinical trials in other leptinrelated diseases, including AN. The involvement of leptin in the endocrine system's response to starvation and appetite regulation suggest that treatment may relieve symptomatology in starving patients. Metreleptin is a mechanistically-based targeted treatment for inborn 
functional leptin insufficiency due to genetic reasons [2]. One of only a few causal treatments is currently available for monogenic sorts of obesity $[25,26,27]$. The treatment also positively affects the reproductive system, cognitive functions, and overall mental health [28]. The potential mechanism that explains the favourable effect mentioned above are the intra- and extra-hypothalamic effects $[29,30]$.

As early as in 1997, researchers tried to determine if treatment with an artificial leptin analog can restore both menstrual function and bone health in energy deficient, amenorrheic and physically active women. During openlabel study, Welt et al. [31] discussed the consequences of 2-3 months of metreleptin therapy $(0.08 \mathrm{mg} / \mathrm{kg}$ body weight). Bone mineral density did not change significantly after intervention. However, increases in bone formation markers have been shown. In three of the eight women a rise in follicular size and number and an ovulatory cycle during the study were observed, while none of the patients within the control group resumed menses.

Chou et al. [32] noticed that after 4 months of therapy with metreleptin, 7 out of 10 treated women experienced revival of menses, coexistent with significant increases in estrogen and progesterone compared to placebo. Authors confirm improvement of bone formation. In the study 20 exercising young women with hypoleptinemia and hypothalamic amenorrhea participated, eleven of them received metreleptin and 9 were compared as placebo group. As in earlier examinations, metreleptin improved bone health: increased bone mineral content (BMC) and attended increase bone mineral density (BMD) at the lumbar spine [14].

In 2020 Milos et al. published the results of a study in which they assessed short-term metreleptin treatment of patients with anorexia nervosa. Three females with hyperactivity were administered off-label with the medication for up to 14 days to examine the drug's effect on leptin levels and reduction in hyperactivity. All patients received three main courses and three interim meals (a total of six meals per day) with 2700-3000 kcal/ day. Two patients gained (1200 and 700 grams) during pharmacotherapy, while one of them lost 200 grams. The metreleptin treatment allowed for decreased activity, repetitive food thoughts, inner restlessness, and weight phobia in two individuals. Hunger was continuously rated as almost absent, and fear of weight gaining decreased during dosing. The examined group reported improvement in their concentration and reducing mood symptoms. The participants more easily initiated personal contacts. The authors point out that the concomitant increase in body mass is expected over time to result in endogenous leptin secretion sufficient to maintain the behavioural, emotional and metreleptin-induced improvements [18].

\section{Conclusions}

Individuals suffering from AN have abnormal serum leptin and other adipokine levels, consistent with too low body fat. Normalizing serum leptin level positively impacts the female reproductive system, markers of bone health, cognitive functions, and mood. Focusing on leptin-related changes is a promising approach to improve AN management. Assessment of leptin in blood during and after AN treatment could be a useful tool for therapy monitoring. Metreleptin could turn out to be the drug with a potent and rapid-onset antidepressant effect in depression among individuals with ED. Its ability to improve hormone status and bone health could reverse unfavourable changes induced by diet restriction. However, the results of studies remain insufficient and need further investigation on larger groups of patients.

\section{Conflict of interest}

The authors have declared no conflict of interest.

\section{References:}

1. Morris J., Twaddle S. Anorexia nervosa. BMJ. 2007;334: 894-898.

2. Hebebrand J., Milos G., Wabitsch M., Teufel M., Führer D., Bühlmeier J., Libuda L, Ludwig C., Antel J. Clinical Trials Required to Assess Potential Benefits and Side Effects of Treatment of Patients With Anorexia Nervosa With Recombinant Human Leptin. Front Psychol. 2019;10:769.

3. Keski-Rahkonen A., Hoek H.W., Susser E.S., Linna M.S., Sihvola, E., et al. Epidemiology and course of anorexia nervosa in the community. American Journal of Psychiatry. 2017;164: 12591265.

4. Schorr M., Miller K.K. The endocrine manifestations of anorexia nervosa: mechanisms and management. Nat Rev Endocrinol. 2017;13: 174-186.

5. Hebebrand J., Albayrak 0. Leptin treatment of patients with anorexia nervosa? The urgent need for initiation of clinical studies. European Child \& Adolescent Psychiatry; New York. 2012, 21: 63-6.

6. Solmi F., Downs J.L., Nicholls D.E. COVID-19 and eating disorders in young people. Lancet Child Adolesc Health. 2021;5: 316-318.

7. Tyszkiewicz-Nwafor M., Adipocytokiny i objawy psychopatologiczne u pacjentek z jadłowstrętem psychicznym [online]. 2012. [dostęp: 29 październik 2021]. Dostępny w Internecie: http://www.wbc.poznan.pl/Content/245836/PDF/ index.pdf

8. Mechanick J.I., Zhao S., Garvey W.T. The AdipokineCardiovascular-Lifestyle Network: Translation to Clinical Practice. J Am Coll Cardiol. 2016; 68: 1785-1803.

9. Coelho M., Oliveira T., Fernandes R. Biochemistry of adipose tissue: an endocrine organ. Arch Med Sci. 2013;9: 191-200.

10. Karageorgiou V., Furukawa T.A., Tsigkaropoulou E., Karavia A., Gournellis R., Soureti A., Bellos I., Douzenis A., Michopoulos I. Adipokines in anorexia nervosa: a systematic review and metaanalysis, Psychoneuroendocrinology. 2020, 112: 104485

11. Somogyi V., Gyorffy A., Scalise T., Kiss D., Goszleth G., Bartha T., Zsarnovszky A. Endocrine factors in the hypothalamic regulation of food intake in females: A review of the physiologicalroles and interactions of ghrelin, leptin, thyroid hormones, oestrogen and insulin. Nutrition Research Reviews. 
2011; 24: 132-154.

12. Hebebrand J., Muller T., Holtkamp K. et al. The role of leptin in anorexia nervosa: clinical implications. Mol Psychiatry. 2007; 12: $23-35$

13. Gruzdeva O., Borodkina D., Uchasova E., Dyleva Y., Barbarash O. Leptin resistance: underlying mechanisms and diagnosis. Diabetes Metab Syndr Obes. 2019; 12:191-198.

14. Yeung A.Y., Tadi P. Physiology, Obesity Neurohormonal Appetite And Satiety Control. [Updated 2020 Nov 22]. In: StatPearls [Internet]. Treasure Island (FL): StatPearls Publishing; 2021 Jan-. Available from: https://www.ncbi.nlm.nih.gov/books/ NBK555906/

15. Francisco V, Pino J, Campos-Cabaleiro V, et al. Obesity, Fat Mass and Immune System: Role for Leptin. Front Physiol. 2018;9:640.

16. Sienkiewicz E., Magkos F., Aronis K., Brinkoetter M., Chamberland J., Chou S., Arampatzi K., Gao C., Konaris A., Mantzoros C. Long-term metreleptin treatment increases bone mineral density and content at the lumbar spine of lean hypoleptinemic women. Metabolism: clinical and experimental. 2011. 60.1211-21.

17. Wauman J, Zabeau L, Tavernier J. The Leptin Receptor Complex: Heavier Than Expected? Front Endocrinol (Lausanne). 2017;8:30

18. Milos, G., Antel, J., Kaufmann, LK. et al. Short-term metreleptin treatment of patients with anorexia nervosa: rapid on-set of beneficial cognitive, emotional, and behavioral effects. Transl Psychiatry. 2020(10):303.

19. Schorr M, Klibanski A. Anorexia Nervosa and Bone. Current Opinion in Endocrine and Metabolic Research. 2018 Dec;3:7482.

20. Fraga Á., Carreira M., Izquierdo A., Dieguez C., López M., Gutierrez E. Temperature but not leptin prevents semistarvation induced hyperactivity in rats: implications for anorexia nervosa treatment. Scientific Reports. 2020. 21. Yamada, Yamada-Goto, Nobuko \& Katsuura, Goro \& Ochi, Yukari \& Ebihara, Ken \& Kusakabe, Toru \& Hosoda, Kiminori \& Nakao, Kazuwa. Impaired CNS Leptin Action Is Implicated in Depression Associated with Obesity. Endocrinology. 2011.152. 2634-43. 10.1210/en.2011-0004.

21. Oral E., Gorden P., Cochran E., et al. Long-term effectiveness and safety of metreleptin in the treatment of patients with partial lipodystrophy. Endocrine. 2019;64(3):500-511.

22. Fiorenza C., Chou S., Mantzoros C. Lipodystrophy: pathophysiology and advances in treatment. Nat Rev Endocrinol. 2011; 7:137-150.

23. Chou K., Perry CM. Metreleptin: first global approval. Drugs. 2013; 73:989-97.

24. Huvenne H., Dubern B., Clément K., Poitou C. Rare Genetic Forms of Obesity: Clinical Approach and Current Treatments in 2016 Obes Facts. 2016; 9:158-173.

25. Hainerová I., Lebl J. Treatment options for children with monogenic forms of obesity. World Rev Nutr Diet. 2013; 106:105-12.

26. Kühnen P., Wiegand S., Biebermann H. Pharmacological treatment strategies for patients with monogenic obesity. Journal of Pediatric Endocrinology and Metabolism. 2020; 33: 967-973.

27. Quennell J., Howell C., Roa J., Augustine R., Grattan D., Anderson G. Leptin deficiency and diet-induced obesity reduce hypothalamic kisspeptin expression in mice. Endocrinology. 2011; 152:1541-50.

28. Paz-Filho G., Wong M., Licinio J. The procognitive effects of leptin in the brain and their clinical implications. Int J Clin Pract. 2010, 64: 1808-1812.
29. Swieten M., Pandit R., Adan R., Plasse G. The neuroanatomical function of leptin in the hypothalamus. J Chem Neuroanat. 2014; 61-62:207-20.

30. Welt C., Chan J., Bullen J., Murphy R., Smith P., DePaoli A., Karalis A., Mantzoros C. Recombinant human leptin in women with hypothalamic amenorrhea. N Engl J Med. 2004;351: 987-97.

31. Chou S., Chamberland J., Liu X., Matarese G., Gao C., Stefanakis R., Brinkoetter MT., Gong H., Arampatzi K., Mantzoros CS. Leptin is an effective treatment for hypothalamic amenorrhea. Proc Natl Acad Sci U S A. 2011;108: 6585-90.

\section{Corresponding author}

Zuzanna Rząd

Independent Public Clinical Hospital No 1 in Lublin, Poland

e-mail: rzadzuzanna@gmail.com

Otrzymano: 18.11.2021

Zrecenzowano: 02.12.2021

Przyjęto do druku: 09.12.2021 